\title{
タスク・アンビエント対応の全空気式放射空調方式に関する研究 STUDY ON ALL AIR RADIATION AIR-CONDITIONING SYSTEM OF TASK AMBIENT
}

\author{
木幡悠士*, 羽山広文**, 関口圭輔*** \\ Yuji KOHATA, Hirofumi HAYAMA and Keisuke SEKIGUCHI
}

\begin{abstract}
In this study, it is an object of the establishment of design methodologies for all pneumatic radiation air-conditioning system of the task ambient correspondence, the expansion of the design documents. A large-scale experiments is carried out about all air radiation air conditioning system of the task ambient using with a membrane radiation unit to the verification of comfort. And We Performed a case study of design for each condition of all air radiation air-conditioning system. We considered the effect of the design and conditions of this system for comfort, and consider how to easily estimate, the effect of the design and conditions of this system for comfort.
\end{abstract}

Keywords : Thermal comfort index, Radiation air conditioning, Task ambient air conditioning 快適性指標，放射空調，タスク・アンビエント空調

\section{1. はじめに}

近年の環境負荷低減に対する意識の高まりを受け、オフィスビル の空調用エネルギーを削減するため、クールビズ、ウオームビズと いった室内の空調設定温度を緩和寸る取り組みがとられている。し かし、室内の環境改善がなされないまま空調設定温度を上昇させる 取り組みは、室内の温熱環境を悪化させる可能性がある。室内の温 熱環境の悪化は居住者の労働生産性の低下を生じ 1)、執務空間とし ての責務を果たすことが出来なくなる。そのため、空調用エネルギ 一の削減を目的とした空調設定温度の緩和は、温熱環境の向上と合 わせて実施する必要がある。

温熱環境を評価するため、温熱環境の 6 要素 (代謝量・着衣量・室 温・放射温度・気流・湿度)を用いる $\mathrm{PMV}^{2)}$ や、SET ${ }^{* 3)}$ といった指標 が一般的に用いられており、室温や湿度だけでは温熱快適性を評価 することはできないことは周知の事実である。冷房運転時を例に挙 げると、空調設定温度を上げることにより人体からの熱の放出がさ れづらくなる。その際、快適性を同程度とするためには、温度以外 の温熱環境要素を調整し、人体からの熱の放出を促す必要がある。

しかし、実際は多くの事例において、温度ならびに湿度を中心に した設備システムの計画・設計や運用がなされることが多い ${ }^{4)}$ 。環 境負荷低減オフィスの実現に向け、温度、湿度以外の温熱環境要素 を含めて定量的な検討を行った空調計画、設計および運用がなされ ることが重要である。

\section{1 既往の研究}

温熱 6 要素の調整による居住者の快適性の向上や空調用エネルギ 一の削減を目的として、室温を緩和する方法を検討する研究が数多 く行われてきた。大熊ら ${ }^{5,6)}$ は実験、アンケート調査により、夏季 $28^{\circ} \mathrm{C}$ 、冬季 $20^{\circ} \mathrm{C}$ 空調設定温度とした際の、着衣量や気流の影響が 快適性に与える影響を示した。結論として、 $28^{\circ} \mathrm{C}$ 空調で熱的中立を 得るためには、さらなる着衣量の減少に加え、人体に対する平均放 射温度 (以下、MRT) や湿度を低く保つ工夫をし、ある程度の気流を感 じる環境にする必要があると述べている。

気流を制御し、快適性向上や省エネルギーを試みる手法の一つと してタスク・アンビエント空調方式が挙げられる。タスク空調は、 対象空間全域の熱処理を行うアンビエント空調と併用し、居住者の いる範囲に特化した空調を行う。タスク空調を温度調整の観点から 大別すると、送風機のみを用いて室内と等温の空気を吹き出すもの、 または温度を調整した非等温空気を吹き出すものに分類される。李 $ら^{7)}$ は、実験を基に、室温と等温の空気を吹き出す等温型ユニット が、快適性、心理的効果に与える影響を検証している。結果として、 室内設定温度が $28^{\circ} \mathrm{C}$ まは $30^{\circ} \mathrm{C}$ 条件において、タスク空調による気 流制御を行うことにより、涼感を得られること、また、タスク空調 の強弱を居住者に選択可能とすることにより快適感がさらに向上寸 ることを示している。秋元ら ${ }^{8)}$ は被験者実験を基に、非等温空気を 用いたタスク空調が快適性、知的生産性に与える影響を検証してい る。結果として、 $30^{\circ} \mathrm{C} 50 \% \mathrm{RH}$ の設定温湿度において、タスク空調を 使用することにより快適感を得られること、さらに、 $26^{\circ} \mathrm{C} 50 \% \mathrm{RH}$ 条 件と比較した場合、作業効率の低下がみられないことを示した。こ れらの一連の研究は、空調システムをタスク・アンビエント対応と することで、しない場合と比較して空調設定温度の緩和が可能であ ることを実証している。

また、これまでに平均放射温度を調整する空調方式として、放射 冷暖房方式の研究 ${ }^{9-13)}$ が多くされてきた。和田・粕谷ら ${ }^{14-16)}$ は冷温
* (侏N T Tファシリティーズ研究開発本部 修士(工学)

** 北海道大学大学院工学研究院 教授・博士 (工学)

*** (株) N T Tファシリティーズ研究開発本部 博士 (工学)
Research and Development HQ., NTT Facilities Inc., M.Eng.

Prof., Faculty of Eng., Hokkaido Univ., Dr. Eng.

Research and Development HQ., NTT Facilities Inc., D.Eng. 
水による放射冷暖房方式の漏水リスク解消及び経済性向上の観点か ら、タスク・アンビエント対応の全空気式放射冷暖房システムを提 案している。システムの特徴として、パーソナル空調を併用した対 流空調に加え、吹出し口からの放射熱伝達による快適性の向上を期 待するものである。解析や実験、実測を基に温熱環境、経済性の評 価を行っている。

\section{2 研究の課題と目的}

タスク・アンビエント対応の全空気式放射空調方式は、水配管が 不要であり、水方式の放射冷暖房と比較して導入が容易であること から、今後の普及が期待される。これまでの研究では、タスク・ア ンビエント対応の全空気式放射空調方式について検証が行われ、快 適性の優位性が証明されているが、未だ導入事例や検証例は多くな い。

一般的に、空調システムの計画時は、様々な設計条件を組み合わ せ、システムの快適性や省エネルギー性、経済性の検討を行う行為 が必要となる。しかし、タスク・アンビエント対応の全空気式の放 射空調方式については、一般的な空調方式と比較し、検討する設計 条件が多い上、設計に必要な資料の整備や検討手法の確立がなされ ていない。そのため、検討の際にはシミュレーションや模型実験を行 い、設計条件が快適性、省エネルギー性に与える影響を評価する必 要がある。タスク・アンビエント対応の全空気式放射空調方式に関 する研究の課題として、簡易な方法でシステムの導入効果を評価す る手法の確立が挙げられる。

本研究は、快適性と省エネルギー性を両立させるタスク・アンビ エント対応の全空気式放射空調方式の汎用的な設計手法の確立、設 計資料の整備を目的に、以下の事項を検討する。

1). 全空気式放射空調方式を構成する制気口として、膜状の空気吹出 し面を持つ制気口(以下、膜放射ユニット)の基本特性を、実大規 模実験により検討する。

2). 膜放射ユニットを用いたタスク・アンビエント対応の全空気式放 射空調方式の実例についての快適性能を、実大規模実験により検 討する。

3). 全空気式放射空調方式の設計条件毎のケーススタディを行い、本 システムの設計条件が快適性に与える影響を、簡易に推定する手 法を示す。

\section{2. 膜放射ユニットについて}

膜放射ユニットの特徵、また、膜放射ユニットを用いた、タスク・ アンビエント対応の全空気式放射空調の概要を示す。

\section{1 特徵}

膜放射ユニットの外観を図 1 に示寸。膜放射ユニットは一般的な 制気口と同様にダクト等を介して空調機から送られた空気を吹出す。 空調機により温度調整された空気は、膜放射ユニット内部に供給さ れ、繊維状の素材である吹出し面を通じて室内に吹出される。膜放 射ユニットの吹出し面の面積は一般的な制気口の吹出し口面積と比 較して大きい。これには、温熱環境に対して以下の特徵を有する。

一つ目は、気流への影響である。吹出し空気の通過風速を小さくす ることで、在室者にとって不快となるドラフトを抑制する効果が期 待される。二つ目は、MRT への影響である。吹出し面の隙間を吹出 し空気が通過することで、対流熱伝達により、吹出し面の温度は吹
出し空気の温度に近づくと、吹出し面と居住者間の熱放射による熱 交換量が変化する。熱放射を行う吹出し面が大きいことで、居住域 の放射温度は快適側に影響する効果が期待される。

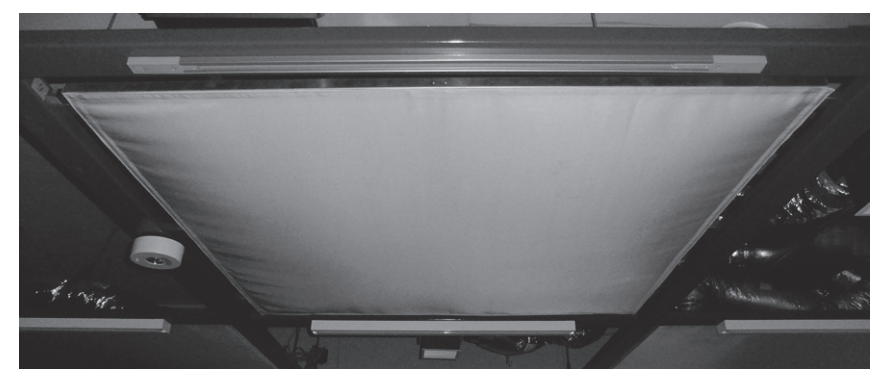

図 1 膜放射ユニット外観

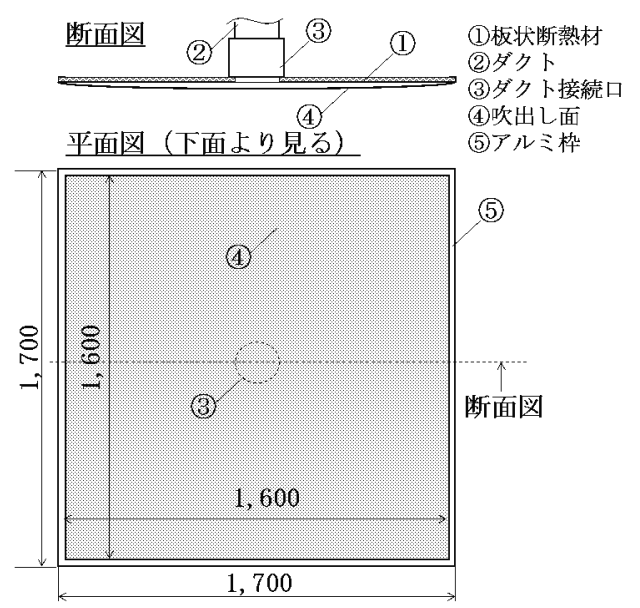

図 2 膜放射ユニット

表 1 膜放射ユニットの仕様

\begin{tabular}{lll}
\hline 仕様 & 外形寸法 $(\mathrm{W} \times \mathrm{D} \times \mathrm{H})[\mathrm{m} \times \mathrm{m} \times \mathrm{m}]$ & $1.7 \times 1.7 \times 0.03$ \\
& 吹出し面寸法 $(\mathrm{W} \times \mathrm{D})[\mathrm{m} \times \mathrm{m}]$ & $1.6 \times 1.6$ \\
& 風量 $\left[\mathrm{m}^{3} /(\mathrm{h} \cdot\right.$ 個 $\left.)\right]$ & 170 \\
\hline \multirow{2}{*}{ 材料 } & 部材 & 材質 \\
\cline { 2 - 3 } & 枠 & アルミ \\
& グラスウールボード $(\mathrm{t} 25)$ \\
& 板状断熱材 & ク゚リプロピレン $($ 難燃性 $)$ \\
\hline
\end{tabular}

\section{2 構成}

膜放射ユニットの模式図を図 2 に、仕様一覧を表 1 に示す。吹き 出し面はポリプロピレン製の織物であり裁断、縫製による部材加工 が可能である。吹出し面の周囲に面ファスナーが縫製されており、 アルミ枠に固定されている。そのため、清掃やクリーニングの際に 吹出し面を取り外す場合は、下面から工具を使わず手作業で脱着を 行う。

膜放射ユニットは、空気式の空調機に接続されるため、対応する 空調機やダンパーの制御により、膜放射ユニットの風量や吹出し温 度の調整が可能となる。空気式であれば空調機の類は問わないため、 制気口としての適用範囲は広い。また、既存の制気口から膜放射二 ニットへ交換することが可能であるため、既存ビルのオフィス空調 システムへの適応が可能である。

\section{3 空調システムの概要}

膜放射ユニットを用いた、タスク・アンビエント対応の全空気式 放射空調の概要を示寸。空調システムイメージを図 3 に示す。本空 
調システムは、アンビエント空調として膜放射ユニット、タスク空 調としてVHS 型の制気口を用いて空調を行う。アンビエント空調と タスク空調は同一の空調機に接続され、どちらからも温度調整され た空気が室内に供給される。タスク制気口が全て閉の場合は、アン ビエント制気口からのみ、温度調整された空気が室内に供給される。 居住者がタスク制気口の開閉を行うことにより、気流性状を選択す ることが可能となる。また、タスク制気口はVHS 型の特徵である水 平、垂直の 2 方向に組み合わされた空気整流板の向きを調整するこ とにより、拡散半径や風向の微調整が可能となる。低温の吹出し空 気による吹出し口における結露の発生や、ドラフトの発生を抑制す るため、空調機が顕熱処理のみを行う送水温度とし、潜熱処理は湿 度調整用の外調機にて行う。

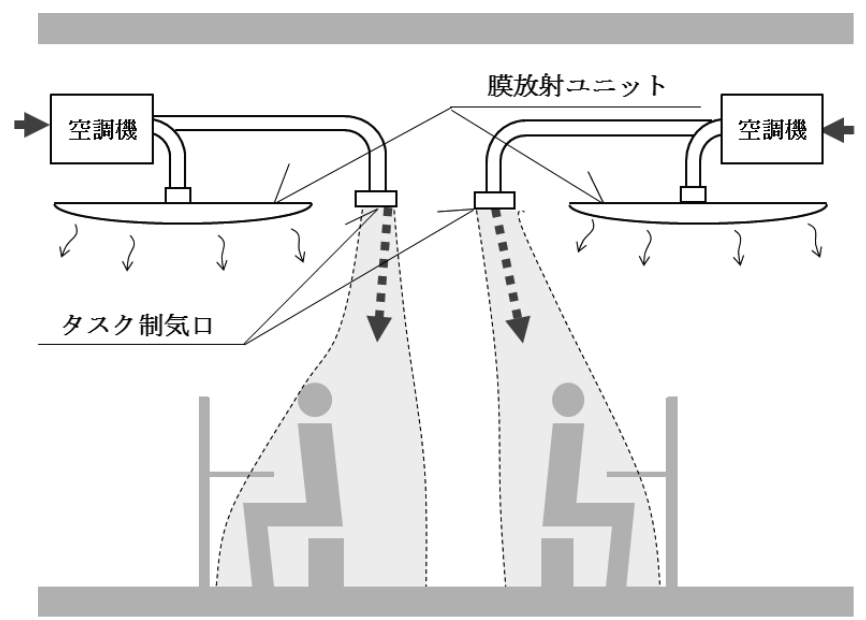

図 3 空調システムイメージ

\section{3 実大規模実験（基本特性検討）}

膜放射ユニットとタスク制気口の基本特性を把握するため、実大 規模実験により、冷房運転時の性能検証を行った。

\section{1 実験システムの概要}

環境実験室 (以下、実験室) 内の一部に、2.3 で述べた空調システ ムの一部を模擬して構築した。空調機は高顕熱型ファンコイルユニ ット (以下: FCU) とした。実験室仕様を表 2 に、実験機器仕様を表 3 に、実験室概要を図 4 に, 実験室空調システムを図 5 に示す。膜放射

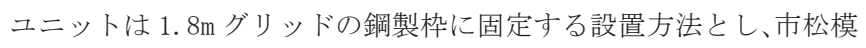
様状に配置した。風量計測は前後の圧力差を検知することで風量を 測定するバロメーターを用いて行った。タスク制気口の空気整流板 は全て鉛直下向きに向けて実験を行った。FCU 一供給される冷水温 度は $17^{\circ} \mathrm{C}$ で一定になるように、3 方電磁弁を自動で制御した。FCU の吹出し風量は全ての実験において固定とした。室内の冷房負荷は 模擬発熱体から発生させるものとした。模擬発熱体は木製の箱の内 部に電熱線とファンを組み込んだものとし、発熱量は抵抗值を変更 することにより調整した。模擬発熱体からの発熱量は電力計にて計 測した。

\section{表 2 実験室仕様}

\begin{tabular}{lrl}
\hline 内部寸法 & 奥行 $(6.4[\mathrm{~m}]) \times$ 幅 $(16.0[\mathrm{~m}]) \times$ 高さ $(3.9[\mathrm{~m}])$ \\
天井高さ & 天井高さ $2.7[\mathrm{~m}]$, 天井裏懷 $1.2[\mathrm{~m}]$ \\
床面仕様 & モルタル充填パネル $(\mathrm{t}=100[\mathrm{~mm}])+$ 二重床 $(\mathrm{t}=50[\mathrm{~mm}])$ \\
壁・天井面仕様 & ウレタンサンドイッチパネル $(\mathrm{t}=100[\mathrm{~mm}))$ \\
\hline
\end{tabular}

表 3 実験機器仕様

\begin{tabular}{llc}
\hline $\mathrm{FCU}$ & 台数 $[$ 台 $]$ & 2 \\
& 風量 $\left[\mathrm{m}^{3} / \mathrm{h}\right]$ & 1020 \\
\hline 膜放射ユニット & 個数 $[$ 個 $]$ & 6 \\
& 風量 $\left[\mathrm{m}^{3} / \mathrm{h} /\right.$ 個 $]$ & 170 \\
& 吹出し風速 $[\mathrm{m} / \mathrm{s}]$ & 0.018 \\
& 面風量 $\left[\mathrm{m}^{3} /\left(\mathrm{m}^{2} \cdot \mathrm{h}\right)\right]$ & 66 \\
\hline タスク制気口 & 個数 $[$ 個 $]$ & 6 \\
& 制気口種別 & VHS \\
& 風量 $\left[\mathrm{m}^{3} / \mathrm{h} /\right.$ 個 $]$ & 170 \\
& 吹出し口寸法 $[\mathrm{mm} \times \mathrm{mm}]$ & $175 \times 175$ \\
\hline 模擬発熱体 & 寸法 $(\mathrm{W} \times \mathrm{D} \times \mathrm{H})[\mathrm{mm} \times \mathrm{mm} \times \mathrm{mm}]$ & $420 \times 450 \times 470$ \\
\hline
\end{tabular}
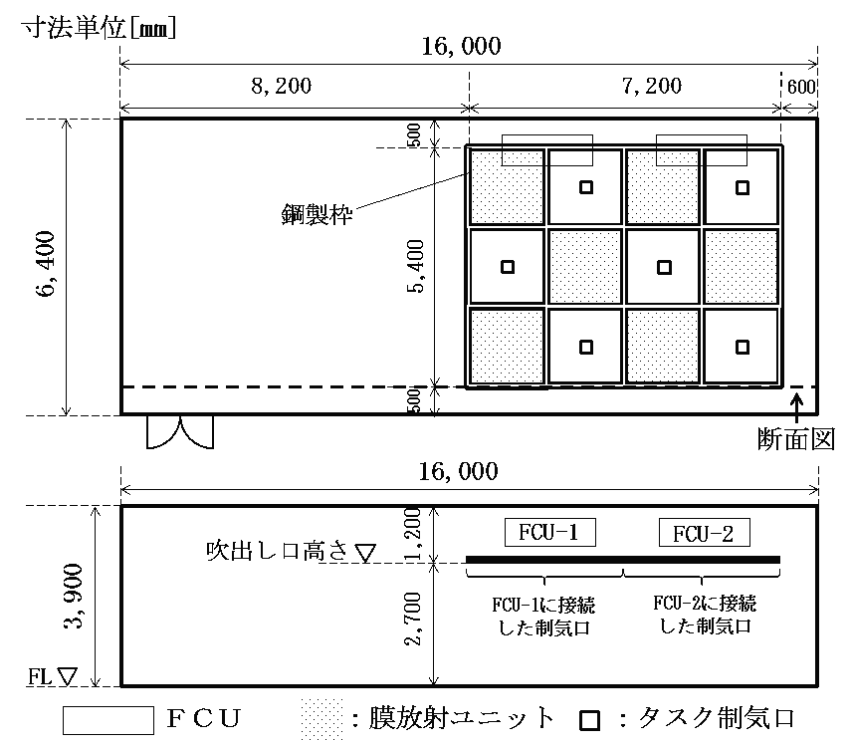

図 4 実験室概要 （上：平面図、下：断面図）

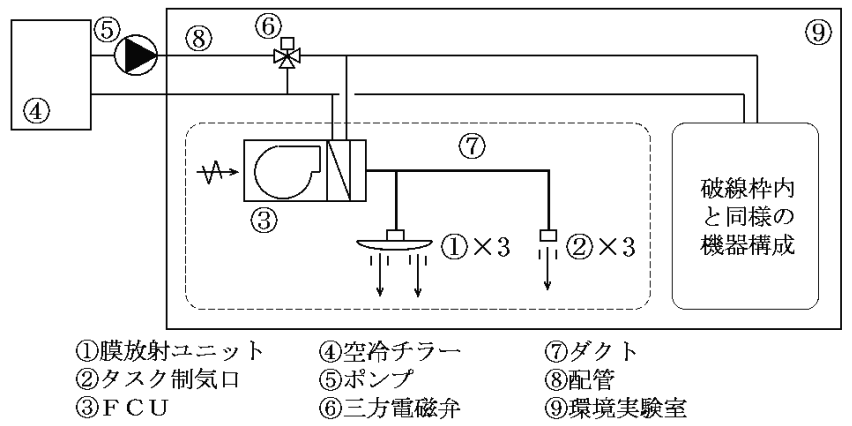

図 5 実験室空調システム （ダクト配管系統図）

\section{2 実験条件（基本特性検討）}

3.1 の実験システムを用い、膜放射ユニットにおける吹出し面の 表面温度、膜放射ユニット下方の風速およびタスク制気口下方の風 速について検討した。測定項目を表 4 に、計測点の平面図を図 6 に 示す。模擬発熱体から5200W（867W/個）を発熱させた状態で FCU2 台による冷房運転を行い、FCU の吹出し温度、室内の空気温度の計 測值が安定収束した後に計測を行った。

\section{3 表面温度計測結果（基本特性検討）}

サーモカメラ (Thermo shot F30:NEC Avio 社製)を用い、膜放射ユ ニット、壁、床、天井の表面温度を測定した。図 7 にサーモカメラ 
により撮影した膜放射ユニットの画像を示す。膜放射ユニット下方 の温度を熱画像により可視化することを目的に、膜放射ユニットの 奥側の端部に障子紙を垂らした。温度計測結果を表 5 に示す。膜部 分表面温度の算出時の放射率は $0.95^{17}$ ) 注 1$)$ 、障子紙表面温度の放射 率は $0.93^{18)}$ とした。熱画像撮影時の膜放射ユニットへの給気温度 は $20.5^{\circ} \mathrm{C}$ であった。熱画像での膜部分の表面温度は、ダクト接続口 付近が低くなったが、膜放射ユニットの端部についても膜放射ユニ ットの表面温度が室内空気温度、周囲表面温度よりも低下し、吹出 し温度に近づくことが確認された。

\section{4 風速測定結果（基本特性検討）}

膜放射ユニット下方の風速の計測点と測定結果を図 8 に示す。計 測値は、15 分間の平均值とした。執務室机上面相当における平均風 速は $0.11 \mathrm{~m} / \mathrm{s}$ 以下となった。また、F L $+1000 \mathrm{~mm}$ 以下における各計 測点の風速はほぼ同值となった。居住域において、静穏とされる風 速 ${ }^{19)} 0.15 \mathrm{~m} / \mathrm{s}$ 以下に収まり、膜放射ユニットがドラフトを生じない ことを確認した。次に、タスク制気口下方の風速の計測点と測定結 果を図 9 に示寸。吹出し口の直下を中心として FL+1000 mm における 風速は $0.3 \mathrm{~m} / \mathrm{s} \sim 0.6 \mathrm{~m} / \mathrm{s}$ となった。また、床面近傍の $\mathrm{FL}+150 \mathrm{~mm}$ にお いても各計測点で約 $0.3 \mathrm{~m} / \mathrm{s}$ の風速となり、タスク空調からの気流が 指向性と天井高さ以上の到達距離を有していることを確認した。

表 4 測定項目

\begin{tabular}{llc}
\hline & \multicolumn{1}{c}{ 測定項目 } & 測定機器 \\
\hline 温度 & 室内代表点 & T 型熱電対 \\
風速 & 制気口下方 & 熱線風速計 \\
表面温度 & 膜部分、障子紙、壁、床、天井 & サーモカメラ \\
\hline
\end{tabular}

\section{表 5 温度計測結果}

\begin{tabular}{|c|c|c|c|c|c|c|}
\hline 測定項目 & \multicolumn{6}{|c|}{ 測定值 $\left[{ }^{\circ} \mathrm{C}\right]$} \\
\hline 膜部分表面温度 & \multicolumn{2}{|c|}{ A 23.8} & \multirow{2}{*}{\multicolumn{2}{|c|}{$\begin{array}{l}\text { B } 23.0 \\
\text { D } 25.5\end{array}$}} & \multicolumn{2}{|c|}{ C 22.5} \\
\hline 障子紙表面温度 & & & & & & \\
\hline 床表面温度 & \multicolumn{6}{|c|}{24.7} \\
\hline 壁表面温度 & \multicolumn{6}{|c|}{25.1} \\
\hline 天井表面温度 & \multicolumn{6}{|c|}{25.2} \\
\hline \multirow[t]{3}{*}{ 室内空気温度 } & \multicolumn{6}{|c|}{ FL からの距離 $[\mathrm{mm}]$} \\
\hline & +150 & +500 & +1000 & +1500 & +2000 & +2500 \\
\hline & 26.2 & 26.5 & 26.7 & 27.3 & 26.9 & 27.2 \\
\hline
\end{tabular}

\section{寸法単位 $[\mathrm{mm}]$}

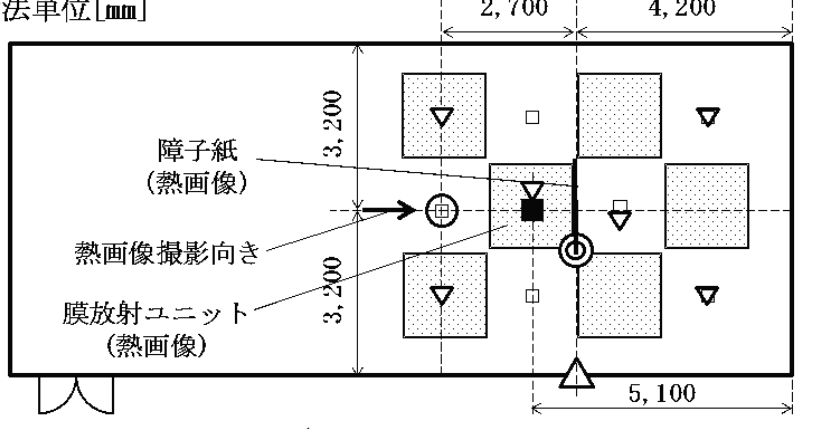

() : 床表面温度 $(\mathrm{F}++0 \mathrm{~m}) \quad \triangle$ : 壁表面温度 $(\mathrm{EL}+1.1 \mathrm{~m}) \quad \nabla:$ 模擬発熱体

$\bigcirc$ : 天井表面温度 $(F L+3.9 n) \quad \square$ : 膜放射ニニット $\square$ : タスク制気口

口 : 室内空気温度 ( $F L+0.15 \mathrm{~m},+0.5 \mathrm{~m},+1.0 \mathrm{~m},+1.5 \mathrm{~m},+2.0 \mathrm{~m},+2.5 \mathrm{~m})$

図 6 計測点 (平面図)

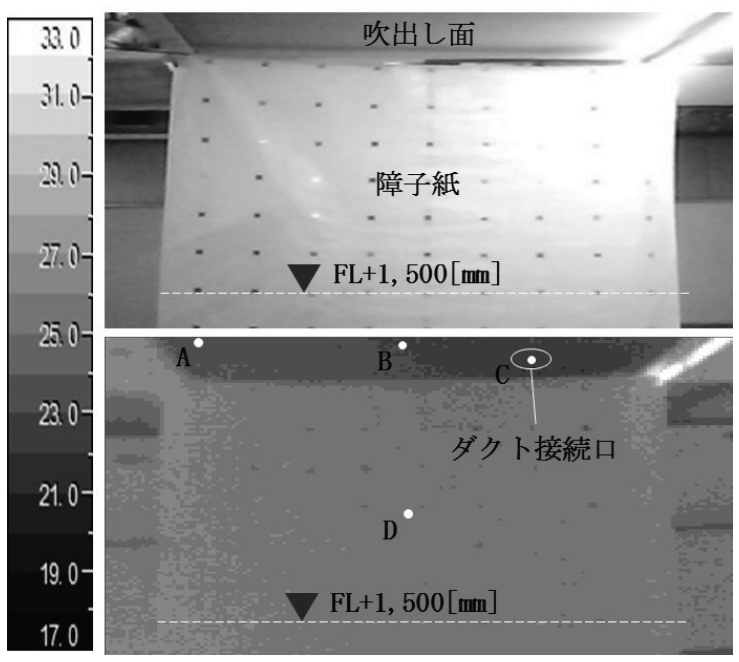

図 7 膜放射ユニットと障子紙 (実画像 (上)、熱画像 (下))

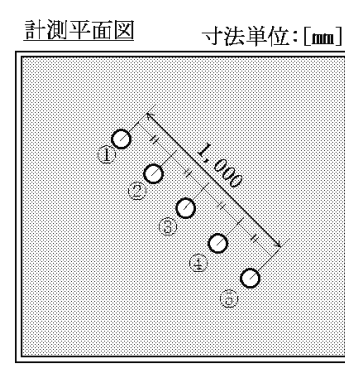

(1) 〜鸟)(計測高さ : FL+ $150,500,1000,1500,2000,2500)$

図 8 風速測定結果（膜放射ユニット下方）

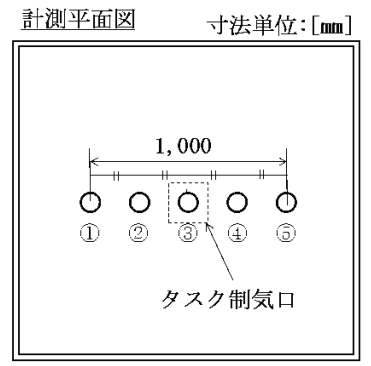

(1) （5) (計測高さ : FL+

$150,500,1000,1500,2000,2500)$
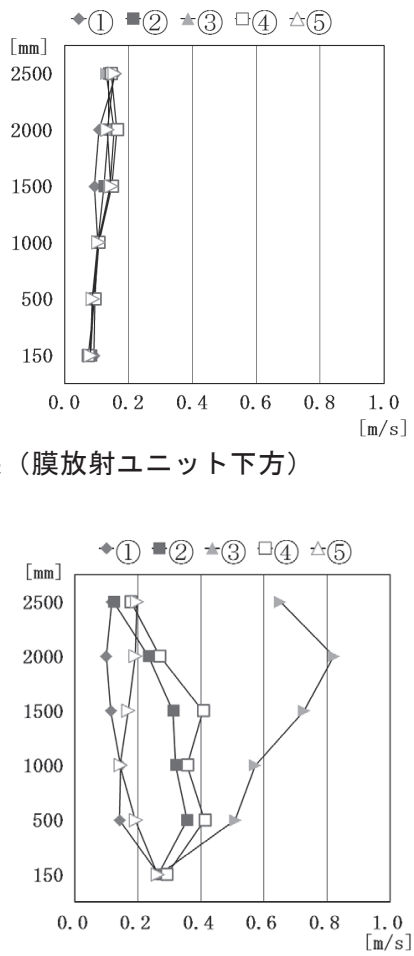

$[\mathrm{m} / \mathrm{s}$

\section{図 9 風速測定結果（タスク制気ロ下方）}

\section{4. 実大規模実験（快適性能検討）}

膜放射ユニットを用いたタスク・アンビエント対応の全空気式放 射空調方式について、冷房運転時における快適性能の検証を行う。

\section{1 快適性能の検証}

3.2 の実験システムを用い、インテリアゾーンに相当する実験エ リアから発生させた泠房負荷を処理し、実験エリア内の快適性指標 を測定した。表 6 に想定したインテリアゾーンの室内条件を示寸。

\section{表 6 室内条件}

\begin{tabular}{lcc}
\hline 室内負荷 & 照明負荷 $\left[\mathrm{W} / \mathrm{m}^{2}\right]$ & 9 \\
& $\mathrm{OA} ・$ 人体顕熱負荷 $\left[\mathrm{W} / \mathrm{m}^{2}\right]$ & 100 \\
\hline 室内空調面積 $\left[\mathrm{m}^{2}\right]$ & & 38.9 \\
膜放射ユニット設置個数 $\left[\right.$ 個 $\left./ \mathrm{m}^{2}\right]$ & 0.15 \\
\hline
\end{tabular}




\section{2 実験条件（快適性能検討）}

実験風景を図 10 に、計測点の平面図を図 11 に示寸。室内空調面 積を想定した 38.9 m²実験室における範囲を図 11 の破線部分にて 示す。表 7 に測定項目を示寸。本実験では、顕熱用空調機の運転に よる室内温熱環境への影響を把握することを目的とし、外調機によ る外気の取り入れや湿度調整は行っていない。PMV の計測は PMV 計 (ブリューウェルケア社製サーマルコンフォート)を用い、機器の設 定值として着衣量 $0.6 \mathrm{c} 10$ 、代謝量 $1.2 \mathrm{met}$ 、水蒸気分圧 $1.5 \mathrm{kPa}$ を与 えた。照明負荷は鋼製枠下部に設置した照明を点灯し発生させた。 模擬発熱体の発熱量は 6500W（929W/個）とした。PMV 測定点 A・B、 グローブ温度測定点における、膜放射ユニットの吹出し面に対寸る 形態係数は 0.10 となった注 2 。評価に用いた測定值は、断面 $\mathrm{A}$ にお ける室内空気温度の值が定常状態になったのち、15 分間の平均值と した。

\section{3 実験結果（快適性能検討）}

断面 $\mathrm{A}$ において測定した室内空気温度を、等温線で表したものを 図 12 に示す。断面 $\mathrm{A}$ における室内空気温度の平均值は $26.8^{\circ} \mathrm{C}$ とな った。タスク制気口下方における室内空気温度は、膜放射ユニット 下方のアンビエント域と比較してやや低い結果となった。温度タス ク制気口と膜放射ユニットは同一の空調機から空気を吹出すが、吹 き出し空気の性状の違いから、タスク制気口の方が低い空気温度と なる傾向にあることを確認した。次に、測定結果を表 8 に示す。測 定点における PMV 、最大上下温度差、風速は基準值内となった。PMV は膜放射ユニット下方、タスク制気口下方共に \pm 0.5 以内となり、 ISO 基準である予測不快者率 (PPD) が 10\%以下になる範囲となった。 計測点の快適性指標が目標とした基準值を満足していることを確認 した。実験室内の熱収支から試算した室内各面の平均表面温度注 3) は、床面 $25.1^{\circ} \mathrm{C}$ 、壁面 $26.5^{\circ} \mathrm{C}$ 、天井面 $26.5^{\circ} \mathrm{C}$ となった。

表 7 測定項目

\begin{tabular}{llcc}
\hline \multicolumn{1}{c}{ 測定項目 } & \multicolumn{1}{c}{ 測定機器 } & 測定点数 & 測定高さ \\
\hline 温度 & $\mathrm{T}$ 型熱電対 & 45 点 & $+1.1 \mathrm{~m}$ \\
$\mathrm{PMV}$ & $\mathrm{PMV}$ 計 & 2 点 & $+1.1 \mathrm{~m}$ \\
グローブ温度 & グローブ温度計 & 1 点 & $+1.1 \mathrm{~m}$ \\
風速 $(\mathrm{m} / \mathrm{s})$ & 熱線風速計 & 1 点 & $+1.1 \mathrm{~m}$ \\
\hline
\end{tabular}

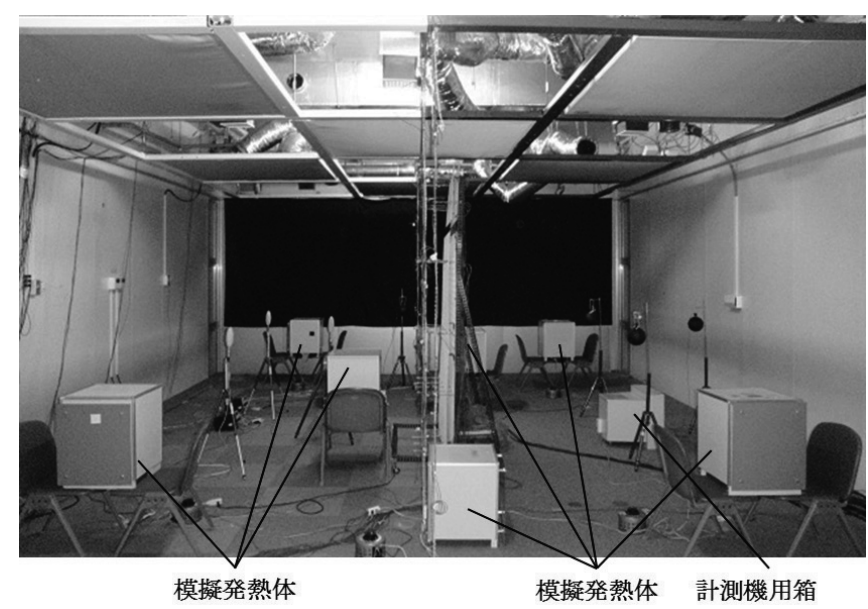

図 10 実験室 検証風景

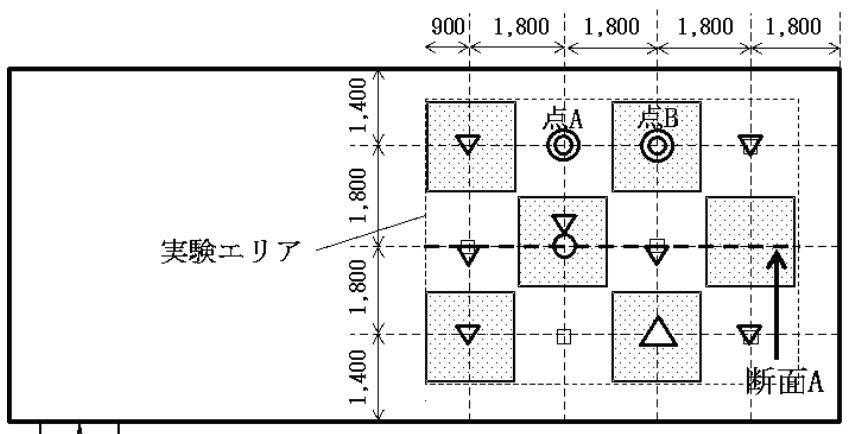

U

. : 温度 $(0.9 \mathrm{~m}$ 間隔、FL+0.1m, $+0.6 \mathrm{~m},+1.1 \mathrm{~m}, 1.7 \mathrm{~m}, 2.2 \mathrm{~m})$

O: 風速 $(\mathrm{FL}+1.1 \mathrm{~m}) \quad \triangle: h^{*} n-T^{*}$ 温度 $(\mathrm{FL}+1.1 \mathrm{~m})$

(Q) : PMV $(F L+1.1 \mathrm{~m})$

$\nabla:$ 模擬発熱体

図 11 計測点平面図

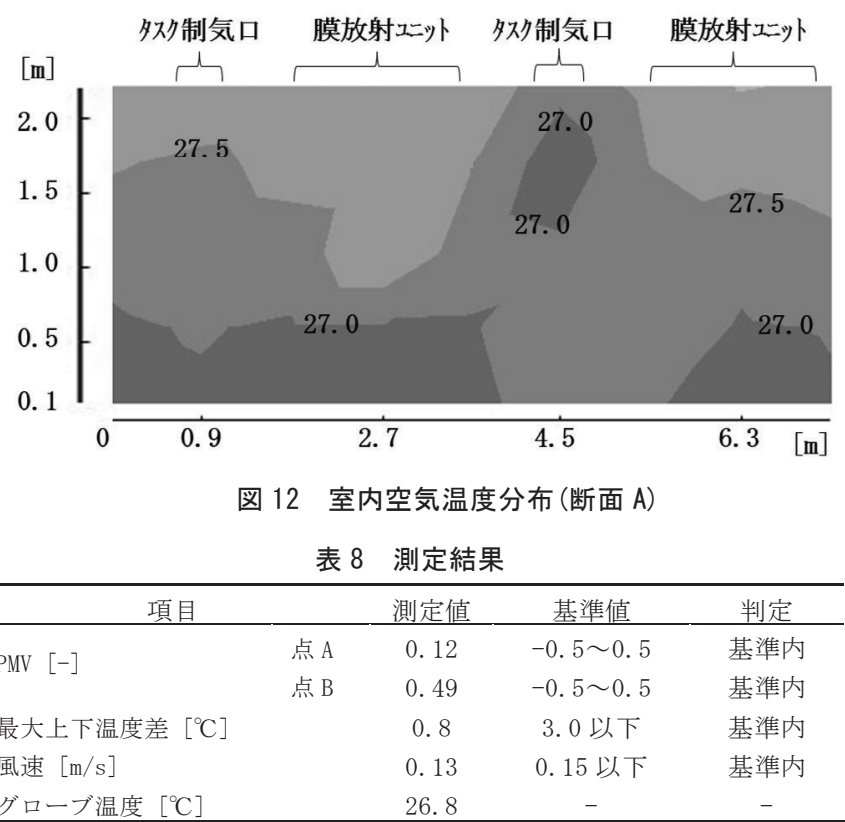

\section{5. 設計条件が快適性に与える影響}

全空気式放射空調方式の設計条件毎のケーススタディを行い、シ ステム設計条件が快適性に与える影響を簡易に推定する手法を示す。

5. 1 ケーススタディ

天井吹出し方式の全空気式放射空調方式における MRT は、吹出し 面の面積に影響を受ける。オフィスのレイアウト計画と整合を図り、 天井の意匠性等を含め検討寸る点から、吹出し口の面積や形状は基 本計画時から想定する必要がある。また、MRT は吹出し面の表面温 度にも影響を受ける。吹出し面は空調機の吹出し空気に直接さらさ れる為、空調機の吹出し温度と相関を持つ。空気式の空調設備にお いて、吹出し温度は設計条件の一つであり、吹出し温度の見直しは システム全体構成に影響を与える可能性がある。更に、運用面にお いて、吹出し面の表面温度は、室内側の条件や空調機の稼働状況に より変動すると考えられるため、設計条件として計画当初から検討 を行う必要がある。

上記の想定を基に、天井吹出し面の面積と表面温度を変数とし、 MRT に与える影響についてケーススタディを行った。MRTの算出条件 を表 9 に示す。算出方法を以下に示す。室内の微小点 $d i$ における平 
均放射温度 Tri は、形態係数を用いた近似式 ${ }^{18)}$ を用いると式(1)で 表すことができる。

$$
\begin{aligned}
T_{r i} & =\sum_{j=n} F_{i j} T_{j} \\
T_{r i} & : \text { 点 } d i \text { における平均放射温度 }\left[{ }^{\circ} \mathrm{C}\right] \\
F_{i j} & : \text { 点 } d i \text { からの各面に対する形態係数 }[-] \\
T_{j} & : \text { 各面の表面温度 }\left[{ }^{\circ} \mathrm{C}\right]
\end{aligned}
$$

微小点 $d i$ から天井面 $J$ に対する形態係数は式(2) として示され る ${ }^{18)}$ 。式(2)の計算を四則演算を用いて簡易に行うため、微小点 $d i$ を微小面 $d A i 6$ 面が集合した立方体に置き換えた場合、Eckert の式 18)を用いることにより、式(3)にて表すことができる。

$$
\begin{aligned}
& F_{i j}=\int_{A_{j}} \frac{\cos \phi i \cos \phi j}{\pi r^{2}} d A_{j} \\
& F_{i j}=\sum_{k=6} \sum_{j=n} F_{i j k} \frac{1}{2 \pi}\left\{\frac{a}{\sqrt{a^{2}+h^{2}}} \tan ^{-1} \frac{b}{\sqrt{a^{2}+h^{2}}}+\frac{b}{\sqrt{b^{2}+h^{2}}} \tan ^{-1} \frac{a}{\sqrt{b^{2}+h^{2}}}\right\} \\
& F_{i j} \quad: \text { 点 } d i \text { からのある面に対する形態係数 }[-] \\
& F_{i j k} \quad: \text { 微小面 } d A i \text { からのある面に対する形態係数 }[-] \\
& a, b \quad: \text { 天井面 } J \text { の平面寸法 }[\mathrm{m}] \\
& h \quad: \text { 点 } d i \text { からのある面までの距離 }[\mathrm{m}]
\end{aligned}
$$

天井面積 $A$ に対する、天井吹出し面 $A r$ の比を天井放射面積率 $R$ と定義する。平均放射温度の算出点に対し、天井吹出し面が一様に 配置され、吹出し面と吹出し面以外の表面温度はそれぞれ同值と仮 定した場合、天井放射面積率 $R$ を用いて放射面の形態係数を式 (4) で表す。

$$
\sum_{j=n} F_{i r j}=R F_{i A}
$$

$F_{i A} \quad:$ 点 $d i$ からの天井面に対する形態係数 [-]

$F_{i r j} \quad$ : 点 $d i$ からのある放射吹出し面に対寸る形態係数 [-

表 9 MRT の算出条件

\begin{tabular}{lc}
\hline 算出点高さ $[\mathrm{m}]$ & $\mathrm{FL}+1.1$ \\
天井面高さ $[\mathrm{m}]$ & $\mathrm{FL}+2.7$ \\
天井寸法 $[\mathrm{m} \times \mathrm{m}]$ & $3.6 \times 3.6, \quad 7.2 \times 7.2, \quad 14.4 \times 14.4$ \\
室内での位置 & 中央 \\
周囲放射温度 $\left[{ }^{\circ} \mathrm{C}\right]$ & $26 、 28$ \\
吹出し面温度 $\left[{ }^{\circ} \mathrm{C}\right]$ & $14 \sim 24(2$ 刻み) \\
天井放射面積率 $[\%]$ & $0 \sim 100$ \\
\hline
\end{tabular}

\section{2 吹出しロの条件が MRTに与える影響}

室内空気温度毎に、天井放射面積率と MRT の関係を図 13 に示す。 天井放射面積率が増えるほど MRT は低下し、その傾向は膜表面温度 が低い程顕著となる。天井の規模が大きい程、MRT は低下寸る傾向 となった。これは、吹出し面の形態係数が大きくなったためである。 天井面の形態係数は室の規模小さい順から 0.19,0.32, 0.41 となっ た。図 14 を用い、設計条件を基に、本システムが MRT に与える影響 について概算検討を行うことが可能となる。但し、吹き抜け空間の ように天井高さが極端に異なる場合やペリメータン゙ーンなどのよう に、天井面の形態係数や周囲表面温度が大きく異なる場合は、結果 が大きくことなるので個別に検討を要する。
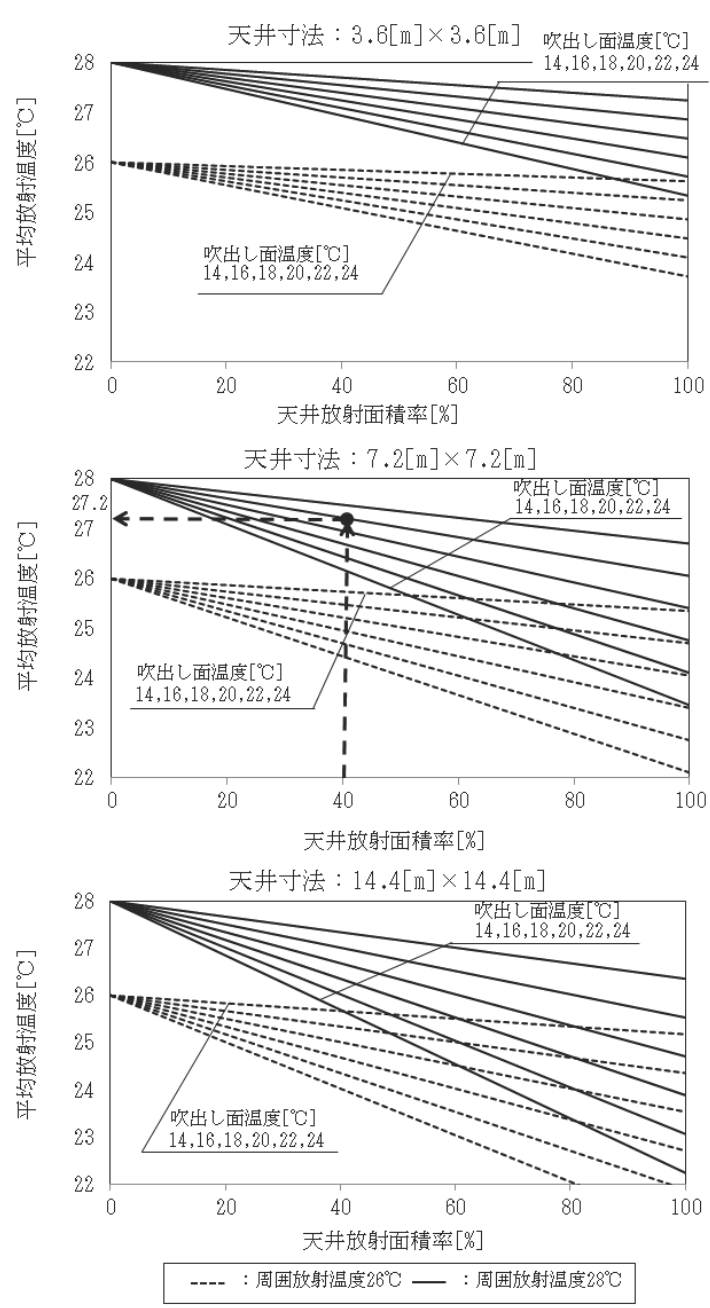

図 13 天井放射面積率と平均放射温度の関係

\section{3 快適性の簡易検討手法}

MRT と風速が快適性指標に与える影響を検討する。室内空気温度 毎に、PMV の值が 0,0.5 となる MRT と風速の值を分布させたものを 図 14 に示す。PMV の算出にあたっては、ファンガーの快適方程式を 用いた ${ }^{18)}$ 。PMV の算出条件を表 10 に示寸。風速を一定とした場合、 MRT を下げることにより、PMV の值を同值としながら、室内設定温度 を高くすることが可能である。また、MRT を一定とした場合、居住 域の風速を大きくすることでも、同様である。第 4 章の計画事例を 基に、図 13 と図 14 を用いて快適性の検討を行う方法を以下に示す。 室内規模は $7.2 \mathrm{~m} \times 7.2 \mathrm{~m}$ 、天井放射面積率を $40 \%$ 、周囲放射温度を $28^{\circ} \mathrm{C}$ 、表面温度注 ${ }^{4)} 22^{\circ} \mathrm{C}$ とすると、MRT は図 13 から $27.2^{\circ} \mathrm{C}$ と読み 取ることができる。室内の温度を $28^{\circ} \mathrm{C}$ とすると、PMV0 0.5 の範囲 に収めるために必要な風速は $0.12 \sim 0.44 \mathrm{~m} / \mathrm{s}$ という結果が図 14 から 得られる。これを基にタスク空調の適合性を確認する。結果、タス ク空調の風速の推定值が条件と適合しない場合、他条件を見直し、 繰り返し快適性指標の確認を行う。このように、計画時の条件の変 更と確認を容易に行うことが可能となる。複数の空調システムを比 較検討する場合、温熱環境のシミュレーションや実験を全てのシス テムについて行うのは困難である。しかし、本手法を用いることに より、初期検討段階における他システムとの比較にも活用されるこ とが期待される。 
本章では、全空気式放射空調方式についてケーススタディを行い、 設計条件が快適性に与える影響を簡易に推定する手法を示した。本 検討手法を初期計画段階の、システム構成検討や複数のシステムの 比較検討の際に用いる簡易検討手法として提案する。

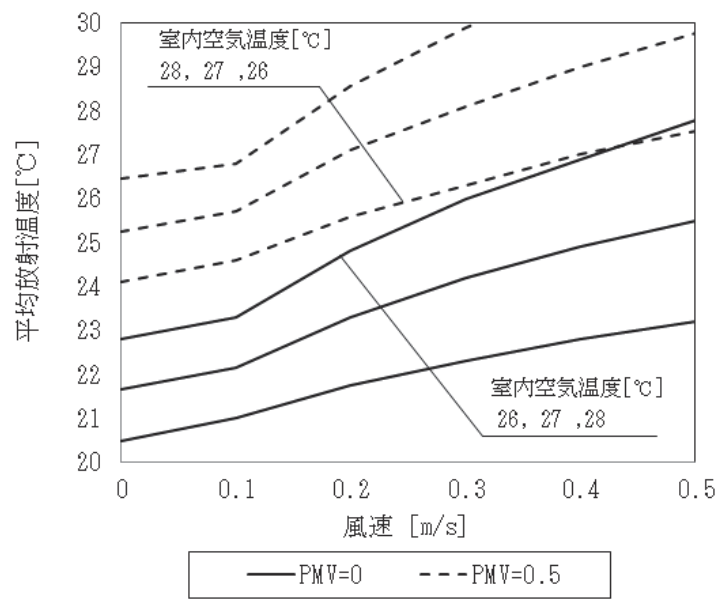

図 14 等 PMV となる風速と平均放射温度の関係

\section{表 10 PMV の算出条件}

\begin{tabular}{llc}
\hline 算出条件 & 代謝量 $[\mathrm{met}]$ & 1.2 \\
& 着衣の基礎熱抵抗 $[\mathrm{clo}]$ & 0.5 \\
& 相対湿度 $[\%]$ & 50 \\
\hline 変数 & 室内空気温度 $\left[{ }^{\circ} \mathrm{C}\right]$ & $26 、 27 、 28$ \\
& 風速 $[\mathrm{m} / \mathrm{s}]$ & $0,0.1,0.2,0.3,0.4,0.5$ \\
\hline
\end{tabular}

\section{6. おわりに}

快適性と省エネルギー性を両立するタスク・アンビエント対応の 全空気式放射空調方式について検討を行い、以下の知見を得た。

1). 実大規模実験を行い、全空気式の放射空調方式を構成する制気口 の基本特性を検証した。膜放射ユニットの端部においても吹出し 面の表面温度が低下寸ることを確認した。又、膜放射ユニット下 方の風速はほぼ一様であり静穏範囲となること、タスク制気口が 指向性と天井高さ以上の到達距離を有していることを確認した。

2). 膜放射ユニットを用いたタスク・アンビエント対応の全空気式放 射空調の実大規模実験を行った。PMV、風速、上下温度差が目標 快適指標值の基準内であることを確認した。

3).タスク・アンビエント対応の全空気式放射空調方式について、設 計条件を変数としたケーススタディを行い、吹出し面の面積と表 面温度、室の規模が MRT に与える影響について検討した。ケース スタディの結果を用い、設計条件が快適性指標に与える影響を簡 易に推定する計画手法を示した。

注

注 1）当該ポリプロピレン繊維素材は、非金属素材であり布としての特徴を 有している。放射波長域は長波長域として、8 14 nm の放射率である 0.95 を用いて表面温度の算出を行った。

注 2）形態係数の算出にあたり、5.1の（1）（4）式を用いた。天井面積は実 験エリアである $38.9 \mathrm{~m}^{2}$ とし、天井放射面積率は $39.4 \%$ として算出した。

注 3 ）実験室内の熱収支から、実験室内各面の表面温度を算出した。算出に 当たり、模擬発熱体の発熱量と照明機器発熱量の和が、 FCU の泠却能力と 室内各面から室外一の熱損失量の和と等しいものとした。FCU の泠却能力 は、 $\mathrm{FCU}$ の機器吹出し温度と吸込み温度の差と風量から算出した。室内各
面の平均表面温度は、室内空気温度と室外空気温度、各面の熱伝導率およ び室内外熱伝達率から算出する。下記計算条件による結果、空調機の冷却 能力は $4403 \mathrm{~W}$ 、室内から室外一の熱移動量は $2447 \mathrm{~W}$ 、内外温度差あたり の実験室内の熱損失量は $196 \mathrm{~W} /\left(\mathrm{m}^{2} \cdot{ }^{\circ} \mathrm{C}\right)$ 、室外空気温度は $14.3^{\circ} \mathrm{C}$ となり、 室内各面の平均表面温度は、床面 $25.1^{\circ} \mathrm{C}$ 、壁面 $26.5^{\circ} \mathrm{C}$ 、天井面 $26.5^{\circ} \mathrm{C}$ とな った。【計算条件】室内総発熱量: $6850 \mathrm{~W}$ 、床面熱伝導率: $0.17 \mathrm{~W} /\left(\mathrm{m} \cdot{ }^{\circ} \mathrm{C}\right)$ 、 壁面、天井面熱伝導率: $0.026 \mathrm{~W} /\left(\mathrm{m} \cdot{ }^{\circ} \mathrm{C}\right)$ 、室内側総合熱伝達率: $9.3 \mathrm{~W} /\left(\mathrm{m}^{2} \cdot{ }^{\circ} \mathrm{C}\right)$ 、 室外側総合熱伝達率: $9.3 \mathrm{~W} /\left(\mathrm{m}^{2} \cdot{ }^{\circ} \mathrm{C}\right) 、 \mathrm{FCU}$ 吸込夕温度 $: 27.2^{\circ} \mathrm{C}(2$ 台の平均值 $)$ 室内空気温度: $26.8^{\circ} \mathrm{C}$ (断面 $\mathrm{A}$ における空気温度の平均值)、 $\mathrm{FCU}$ 吹出し温 度: $20.8^{\circ} \mathrm{C}\left(2\right.$ 台の平均値)、天井裏面積: $102.4 \mathrm{~m}^{2}$ 、床面積: $102.4 \mathrm{~m}^{2}$ 、壁面 積: $174.8 \mathrm{~m}^{2}$

注 4）フローチャートを利用するにあたり、設計与条件として吹出し面温度 を付与寸る必要があるが、本研究の成果は吹出し面温度の汎用的な推定手 法を確立するに至っていない。そのため、吹出し面温度の設定にあたって は、実測值を基にした推定が有効となる。

\section{参考文献}

1）西原直枝,田辺新一:中程度の高温環境下における知的生産性に関する被 験者実験, 日本建築学会計画系論文集,第 568 号, pp33 39,2003.6

2) Fanger, P, O:Thermal comfort, Danish Technical Press, 1970

3) A. P. Gagge, A. P. Fobelets, L. G. Berglund: A Standard Predictive Index of Human Response to the Thermal Environment ASHRAE Transaction Vol. 92, Part 2, pp.709-731, 1986

4) 空気調和・衛生工学会便覧(第 14 版),第 5 部 計画・施工・維持管理,第 5 章 温熱環境計画,pp106～107,2010.2

5）大熊涼子,石野久彌,中山哲士:夏季のオフィスにおける $28^{\circ} \mathrm{C}$ 空調の熱的快 適性に関する研究，日本建築学会環境系論文集,第 618 号, pp31〜 $36,2007.8$

6) 大熊涼子,石野久彌,中山哲士:冬季 $20^{\circ} \mathrm{C}$ 室温における着衣と熱的快適性に 関する研究, 日本建築学会環境系論文集,第 73 巻,第 625 号, pp307〜 $312,2008.3$

7）李成在,田辺新一,野辺達夫:等温気流ユニットを用いたタスク空調の熱的 快適性,日本建築学会環境系論文集,第 575 号,pp75～82,2004.1

8）秋元孝之,松田順平,西原直枝,田辺新一:個人制御による非等温タスク空調 が熱的快適性・知的生産性に与える影響, 日本建築学会環境系論文集,第 582 号,pp75-82,2004.8

9）瀧ヶ崎薰,義恵龍一郎,河原博之,高橋賢治:天井面放射冷暖房システムに関 する研究 (その 1)冷暖房時における温熱環境実測結果,空気調和・衛生工学 会学術講演会論文集,pp477-480,2005.7

10）桑原，何原,塩谷,今井:放射空調システムの室内環境に関する研究(その 1 ～2), 空気調和・衛生工学会学術講演論文集,(3)pp1925-1932,2006.9

11)横江彩,宮部孝典,奥宮正哉,田中英紀ら:放射・対流併用型放射空調システム

に関する研究第 $1 \sim 2$ 報,空気調和 ・ 衛生工学会学術講演論文 集,(1)pp205-212,2007.8

12）岡本茂，三浦光城,山口弘雅,尾本和夫,高岡昌史,岡建雄:天井放射冷暖房用 パネルの性能予測計算方法と実験值の比較, 日本建築学会環境系論文集,第 73 巻,第 624 号,pp221-227,2008.2

13）工藤奈津美,李周好,磯田憲生:天井冷房の快適性評価に関寸る研究,空気調 和・衛生工学会学術講演会講演論文集,(3)pp1341-1344,2001.8

14）和田一樹,粕谷敦, 迫加奈絵，山本麻莉,川口玄ら:タスク・アンビエント対 応膜放射冷房システムに関寸る研究 その $1 \sim 5$, 日本建築学会大会学術講演 梗概集,環境工学 II , pp1077-1086,2010.7

15）和田一樹,迫加奈絵,山本麻莉,古谷恵一,武藤友香ら:タスク・アンビエント 対応膜放射冷房システムを導入したオフィスにおける実測調査 その $1 〜 5$, 日本建築学会大会学術講演梗概集, 環境工学 II, pp1239-1246,2011.7,pp923-924,2012.9

16）左勝旭，武藤友香，石井義章，小林美子,和田一樹ら:環境配慮技術を導入 した先進的なテナントオフィスにおける執務環境評価その $1 \sim 5$, 日本建築 学会大会学術講演梗概集,環境工学 II ,pp401-410,2013.8

17）林電工株式会社 HP，非金属の標準放射率表, http://www.hayashidenko.sannkoubuco.jp/about_rtNm.html ，参 照 2014.10 .25

18）空気調和・衛生工学会便覧(第 14 版),第 1 部,基礎編,2010.2

19）系魚川高穂,羽山広文,絵内正道,山岸浩:病室における睡眠時の対流式冷房 に関する実験的研究, 日本建築学会環境系論文集,第 73 巻, 第 631 号,pp1133-1138,2008.9 


\author{
Yuji KOHATA*, Hirofumi HAYAMA** and Keisuke SEKIGUCHI*** \\ * Research and Development HQ., NTT Facilities Inc., M.Eng. \\ ** Prof., Faculty of Eng., Hokkaido Univ., Dr. Eng. \\ *** Research and Development HQ., NTT Facilities Inc., D.Eng.
}

In recent years, awareness of environmental load reduction is increasing. In order to mitigate the air conditioning temperature setting to reduce air-conditioning energy of an office building, many people are doing efforts of Cool Biz, etc. However, raising the air conditioning temperature setting might exacerbates the thermal environment. Deterioration of the thermal environment in the room, reducing the labor productivity of occupants. Then, the office will not be able to fulfill their responsibilities. For this reason, it is important that performs air conditioning operation plan, and design, including elements airflow, radiation, to achieve both comfort and energy saving.

In the study of history on all air radiation heating and cooling system of the task ambient correspondence, a detailed measurement and analysis, the superiority of comfort has been demonstrated. However, verification and examples of case studies at the moment is small. In the present study, it is an object of the establishment of design methodologies for all air radiation air-conditioning system of the task ambient correspondence, the expansion of the design documents.

In Chapter 2, for the introduction of all air radiation air-conditioning system shows an overview of a membrane radiation unit. A Characteristic of the membrane radiation unit is a big blow-out opening area. The wind speed is low, the membrane radiation unit can suppress draft. Also, since the portion for heat radiation is large, the membrane radiation unit may decrease the MRT.

In Chapter 3, in order to understand the basic characteristics of the membrane radiation unit and task system, the actual large-scale experiments were performed to verify the performance of the cooling operation. The results of the experiment, the whole surface temperature had decreased, and close to the outlet air temperature. Wind speed of the membrane radiation unit has become $0.15 \mathrm{~m} / \mathrm{s}$ or less. In addition, the task system has been confirmation that has a directional and reach of the airflow.

In Chapter 4, for all air radiation air conditioning of the task ambient using with a membrane radiation unit, to carry out the verification of comfort. The air conditioning system is configured at the hands of air inlets of the VHS type membrane radiation unit, as the task air conditioning as ambient air conditioning. The experiment was conducted to verify the comfortable performance in cooling operation. Result, PMV became the range prediction discomfort participation rate (PPD) is less than 10\%. Wind speed of the membrane radiation unit downward was within the range that does not give the feeling of draft. Temperature of the air conditioning of task resulted slightly lower than the area of membrane radiation unit. Air flow of task area had done a local cooling effectively. It was confirmed that this system satisfy with target comfort index by the actual measurement results.

In Chapter 5, to perform a case study of design for each condition of all air radiation air-conditioning system. A result of the case study, MRT was decreased as the film surface temperature is low. Further, as the ceiling radiating area increases, MRT was decreased. Next, I consider the effect of the design and conditions of this system for comfort, and consider how to easily estimate, the effect of the design and conditions of this system for comfort. Figure 14 shows the relationship between ambient temperature, PMV, MRT, wind speed, showed a method for easily considered to meet target comfort indicators. This method might be proposed as a simple study technique to be used when considering the configuration and comparison of the system of basic planning stage. 